\title{
WPS-2018
}

\section{PREREQUISITES FOR A}

DEVELOPMENT-ORIENTED STATE IN THE
DEMOCRATIC REPUBLIC OF THE CONGO

DEVELOPMENT-ORIENTED STATE IN THE
DEMOCRATIC REPUBLIC OF THE CONGO

Mondonga M. Mokoli and Hans P. Binswanger

September 21, 1998 


\section{Table of Contents}

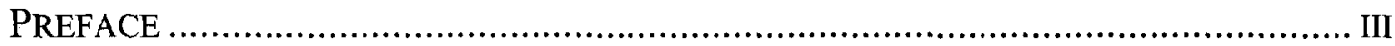

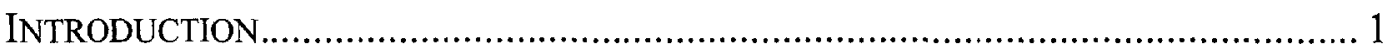

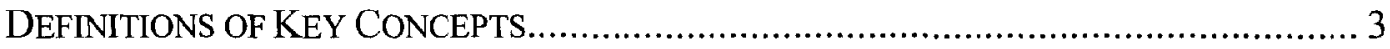

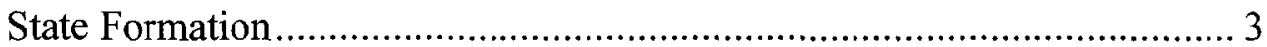

Growth-Oriented State and Development-Oriented State......................... 5

PreREQUisites AND Processes For A Stable AND DEVElopment-ORIENTED

STATE AND THEIR APPLICATION TO THE CONGO .............................................. 6

Adequate Revenues to Finance Essential State Functions ......................... 6

Monopoly Over the Means of Coercion ............................................. 8

Transparent Administration and Professional Bureaucracy ..................... 10

Ability to Ensure Food Supply ........................................................... 11

Representative Institutions to Ensure Accountability.......................... 13

Bargaining Among Equally Powerful Groups........................................ 14

Overall Assessment............................................................................ 17

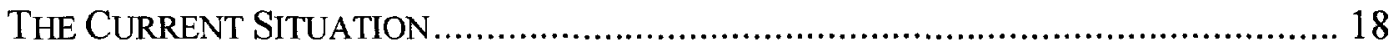

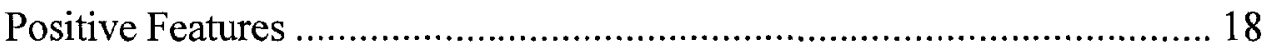

Obstacles................................................................................. 19

IMPLICATIONS FOR DEVELOPMENT STRATEGY IN THE CONGO ............................. 20

IMPLICATIONS FOR EXTERNAL SUPPORT AND THE WORLD BANK GROUP .............. 23

ANNEX - HISTORICAL BACKGROUND OF THE CONGO …................................. 27

SELECTED BIBLIOGRAPHY ................................................................... 31 


\section{Preface}

The purpose of this paper is to stimulate a debate on the conditions which need to exist or be created in the Democratic Republic of the Congo so that it can evolve into a development-oriented state capable of enhancing the welfare of its people. We invite all who are interested in this paper to participate in the debate.

We thank the World Bank Group for its interest in and support of this study. We also thank everybody who took his/her time to review this paper.

We, the authors of this study, are solely responsible for its entire content.

Mondonga M. Mokoli and Hans P. Binswanger

September 21, 1998 


\title{
PREREQUISITES FOR A DEVELOPMENT-ORIENTED STATE IN THE DEMOCRATIC REPUBLIC OF THE CONGO
}

\author{
Mondonga M. Mokoli and Hans P. Binswanger
}

\section{INTRODUCTION}

1. The Democratic Republic of the Congo, formerly known as the Republic of Zaire has, for many years, been in a severe economic and political crisis, culminating in civil war, resulting in the overthrow of President Mobutu Sese Seko by the rebel forces of Laurent Désiré Kabila and the latter becoming the new President. This new President is currently under attack by the same rebel forces that brought him to power and they threaten to overthrow him by a renewed rebellion and civil war. The Congo lacks the basic prerequisites of a stable and development-oriented state, which include a fiscal basis and revenue generating ability, a monopoly over the means of coercion, administrative capabilities, and representative institutions within which bargaining and decisions can take place about development strategies, policies and programs.

2. The international community has tried unsuccessfully to assist the Congo to overcome that crisis on several occasions. During the 1980s, for example, the World Bank Group had, similar to the experience of other lenders and donors, concentrated on the design and implementation of policy reforms and programs conducive to the generation of sustainable growth and poverty reduction in the Congo. However, the programs supported by the Bank, including its last structural adjustment program, achieved little ${ }^{1}$.

3. In 1991, the World Bank and other international lenders and donors retreated from the Congo because the generalized weakness of the state translated into incapacity and unwillingness to carry out these programs. In this post-Mobutu era the Bank faces the question of re-engagement; in the meantime, the economic, social, and political conditions have further deteriorated, along with the essential state capacities.

4. In this study we look at the crisis in the Congo through the lenses of the growing literature on state formation. We assess the strategies which the Congo has to pursue in order to develop a stable and development-oriented state.

\footnotetext{
${ }^{1}$ Winsome J. Leslie, The World Bank and Structural Transformation in Developing Countries. The Case of

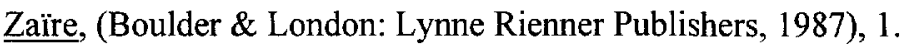


5. In so doing, we take the analytical viewpoints of Barrington Moore, $\mathrm{Jr}^{2}$., Charles Tilly $^{3}$, Richard Sandbrook ${ }^{4}$ and Mick Moore ${ }^{5}$ on state formation and we argue that stable and development-oriented states must fulfill at least the following prerequisites:

(a) Adequate revenue to finance essential state functions;

(b) Monopoly over the means of coercion;

(c) Efficient and transparent administration and bureaucracy, in particular for raising revenue;

(d) The ability to ensure food supply, especially to vocal (usually urban) populations;

(e) Representative institutions which ensure accountability; and

(f) The bargaining among (equally) powerful groups.

6. Obviously, each one of these prerequisites is difficult to achieve, let alone their combination. Each of them must develop internally, but their development can also be facilitated and jump-started by external assistance.

7. The purpose of this study is to enable the World Bank Group and other development institutions and organizations to become aware of the existing body of literature on state formation and, more importantly, its relevance, potential contribution and implications to sustainable development in developing countries. This literature explores, among others, how these prerequisites can arise, as well as the processes that support and/or challenge their occurrence. These processes include, but are not limited to, wars, fiscal crises, and external assistance. These prerequisites and processes, in turn, are likely to generate institutions and organizations of a stable and development-oriented state.

8. This study thus is threefold: 1) it will present the social, political, and economic/material prerequisites and processes that characterize stable and developmentoriented states, and apply each of these prerequisites and processes to the Congo;2) it will

\footnotetext{
${ }^{2}$ Barrington Moore, Jr., Social Origins of Dictatorship and Democracy. Lord and Peasant in the Making of the Modern World, (Boston, MA: Beacon Press, 1967), xi-523.

${ }^{3}$ Charles Tilly, Coercion, Capital, and European States, AD 990-1990, (Cambridge, MA: Basil Blackwell, 1990), 1-260.

${ }^{4}$ Richard Sandbrook, "Hobbled Leviathans: Constraints on State Formation in Africa," in International Journal, XLI, (Autumn 1986), 707-733.

${ }^{5}$ Mick Moore, "Death Without Taxes: Democracy, State Capacity, and Aid Dependence in the Fourth World," in Gordon White and Mark Robinson (eds.) Towards a Democratic Developmental State, (Oxford University Press, Forthcoming).
} 
point out key priorities for a strategy that is conducive to the creation of a developmentoriented state in the Congo; and 3) the study will also discuss how external actors can help create the underlying prerequisites for the formation of a stable and development-oriented state as part of their assistance for economic and social development in the Congo.

9. We first briefly elaborate on the definitions of state formation, as well as on the concepts of growth-oriented state and development-oriented state that we coined and developed from the literature on state formation.

\section{DEFINITIONS OF KEY CONCEPTS}

\section{State Formation}

10. State formation is a complex social phenomenon that encounters very difficult constraints on its way. It has always been, throughout world history, a violent and painful process, with many slow and disorderly starts. The definition of state formation can be found in the large and growing literature on the subject primarily on Europe, as well as on developing countries.

11. Alexander Wendt and Michael Barnett ${ }^{6}$ define state formation as both the building of institutions for territorial control, and the process by which one constellation of societal interests achieves state power and international recognition rather than another. It is, as Charles Tilly ${ }^{7}$ defines, the process of creating coercion-wielding organizations (institutions) that are distinct from households and kinship groups. These organizations exercise clear priority in some respects over all other organizations within a well-defined territory. The formation and transformation of state organizations occur largely as consequences of efforts to conquer and maintain control over the people and property in the territory.

12. The process of state formation also includes the building of city-states, empires, theocracies, and many other forms of government, but excludes tribes, lineage, firms, and churches as such. While many social researchers of politics use the term in this organizational way, some extend it to whatever structure of power exists in a large, contiguous population, and yet others restrict it to relatively powerful, centralized, and differentiated sovereign organizations called nation states.

13. Thomas M. Callaghy ${ }^{8}$ defines state formation as the set of complementary and competing processes that deal with the creation, consolidation, and extension of an organization

\footnotetext{
${ }^{6}$ Alexander Wendt and Michael Barnett, "Dependent State Formation and Third World Militarization," in Review of International Studies, vol. 18, no 2 (April 1993), 321-347.

${ }^{7}$ Charles Tilly, Coercion, Capital, and European States, AD 990-1990, 1-2.

${ }^{8}$ Thomas M. Callaghy, The State-Society Struggle. Zaïre in Comparative Perspective, (New York: Columbia University Press, 1984), 81-82.
} 
of domination over a population in a given territory, using an administrative apparatus backed by a coercive capability and various legitimating ideas. It is a struggle for dominance with internal societal groups and external groups, organizations, and forces of compliance, resources, and the fulfillment of ideal and material interests. State formation is a struggle for internal control, national integration, political unification, and external security.

14. There are, according to Callaghy ${ }^{9}$, essentially three views of state with regard to the relationship between state and society. The first is that state controls society; that society is the object of state, or more precisely, it is the object of statecraft. This view has its roots in the medieval statecraft literature associated with Macchiavelli, Guicciardini, and others. It can be linked to positions that view the state as an organization of domination and exploitation, as well as to Leninist views of Marxist social transformation.

15. The second view is that the state is, and politics in general are, the product of society. This view can be seen in the theoretical writings of John Locke, Jean Jacques Rousseau, SaintSimon, and Karl Marx. The third view, to which we subscribe, is that state and society are partly dependent and partly autonomous arenas of sociopolitical life. They are mutually interdependent spheres in which the degree of dependence and autonomy of each varies over time as power relationships between them change in the struggle for control.

16. The third view is that state and society are intertwined, and the struggle for dominance and autonomy is an ongoing process never to be completely decided one way or the other. The state may be viewed as a ruling organization that competes for power with other political, economic, and social organizations and groups. It has potential to leverage, promote, and mediate change in pursuit of collective ends. We accept this third view of state-society relations and we note that where these relations have been used well, good governance and economies have flourished; whereas where they have not, life has been very difficult.

17. Max Weber ${ }^{10}$ called the state a compulsory political organization with continuous operations, and he argued that the process of state formation essentially entails three types of compliance with continuous operations. The first type of compliance is voluntary normative compliance, which is usually due to consensus on values or outcome; the second is utilitarian compliance, benefiting the individual or groups; and the third type is coercive compliance that is based on compulsion by force, violence, and terror or the threat of them. Any state relies on all three types of compliance, although the relative mix varies greatly from state to state and according to political and economic conditions in place.

\footnotetext{
${ }^{9}$ Thomas M. Callaghy, The State-Society Struggle. Zaïre in Comparative Perspective, 89-90.

${ }^{10}$ Max Weber, Economy and Society, edited by Guenther Roth and Clauss Wittich, (Berkeley: University of California Press, 1978), 2-34.
} 


\section{Growth-Oriented State and Development-Oriented State}

18. We differentiate a growth-oriented state from a development-oriented state, and we nevertheless recognize that they are complementary.

19. A growth-oriented state, over prolonged periods of time, takes policy and resource allocation decisions which create the incentives and effective institutions which will lead to private and public investments, productivity growth, and growth of per capita income. It avoids to take decisions which undermine such growth. As we shall discuss below, the existence of a bargaining equilibrium among powerful social groups is an essential prerequisites for the emergence and sustainability of a growth-oriented state.

20. A development-oriented state is a growth-oriented state but is one which, in addition to taking decisions which enhance growth, also consistently takes decisions which lead to widely shared growth. These include improvements in the welfare of all social groups, and which ensure the economic and environmental sustainability of that growth.

21. In general, a development-oriented state is stable and sustainable. Its institutional design empowers citizens to control the politicians and the government, enables politicians to control bureaucrats, enables the government to place bounds and safeguards on the behaviors of citizens, and it allows the government to ensure economic stability and encourage development.

22. The bargaining equilibrium requested for passage from growth-orientation to development-orientation in the process of state formation can be successful only if, on the one hand, the poor are organized and represented, and, on the other hand, if the natural resources are effectively managed by civil society organizations which will lobby for their sustainable use. Under these conditions bargaining will also lead to social and environmental policies and programs, such as taxes to increase revenues, land reform, rural and agricultural development, urban development, pension, employment, education, housing, health, environment, etc.

23. This study draws its data from secondary analysis and field observations in the Democratic Republic of the Congo, and it builds on the substance of the above literature. Nevertheless, it takes it a step further by simultaneously presenting the requirements for the formation of a stable and development-oriented state and applying them to the Congo, with implications for World Bank and other donors' re-engagement. A brief historical background of the Congo is in the Annex. 


\section{Prerequisites And Processes For a Stable And Development-Oriented STATE AND Their APPLICATION To The CONGo}

\section{Adequate Revenues to Finance Essential State Functions}

24. Presentation: All rulers and governments must be concerned with having an adequate revenue base to finance essential state functions. The state also need funds to promote social harmony and foster capital accumulation. Rulers or ruling elites often need resources to compensate members of the ruling coalition.

25. A strong and stable revenue base can arise from extracting natural resources, taxing agricultural production or from capitalistic production and trade. Mobilizing revenues requires an extractive apparatus which delivers the resources to the state rather than consuming them. Revenues must be mobilized in such a way that the ability of producers and traders to continue to pay in the future is maintained and enhanced. Success in this respect can enlarge the economy and hence the tax base on which the government draws.

26. Consistency to collect revenues can be undermined by a variety of factors. These include extortive taxation which leads to resistance, very high tax rates which undermine the activities taxed, excessive power of intermediaries who appropriate a large share of the taxes that they collect on behalf of the state, or rent seeking and corruption.

27. Tilly ${ }^{11}$ underscores that taxes on flows, stocks, and especially income yield a high return for a given amount of effort at collection and adapt more readily than tribute or rents to alterations in state policy. States with a strong mercantile or capitalistic base have therefore been more conducive to stable revenue streams than agrarian economies. Not only is the tax base lower in agrarian economies, taxes are also hard to collect, especially where population density is low and the population remains subsistence oriented. Revenue collection in agrarian societies has therefore often relied on coercion. Where population densities have been low, central states have rarely been able to convince local rural elites to pass significant shares to the center, without resorting to strong coercive power and even despotic rule. More recently agrarian states had to rely on taxation of export commodities where trade flows, rather than dispersed production, could be taxed.

28. The exploitation of mineral resources provides an alternative tax base to capitalistic production, coercive taxation of peasants, and taxation of agricultural exports. Yet in the quest for taxing mineral production, states face stiff competition from actual or potential private monopolies and from local elites. Imposing its own power to tax mining revenues is therefore a major challenge for any state, especially a weak one.

${ }^{11}$ Charles Tilly, Coercion, Capital, and European States, AD 990-1990, 74-99. 
29. Application: The political economy of Congo has been, as Thomas M. Callaghy ${ }^{12}$ points out, more akin to early modern mercantilism than to more advanced and effective stable and development-oriented states. It has not allowed for the establishment of an adequate and sustainable revenue base to finance essential state functions.

30. As with other sectors, the financial history of the Congo since independence has been very disappointing. During the Second Republic, for example, it was characterized by "la Politique des Grands Travaux" that was funded by a high level of government spending and by a steady accumulation of foreign debt. Regular increases in spending were not, however, matched by a widespread collection of revenue. Rather, the government raised income with the least possible effort. This meant a penal rate of taxation, both direct and indirect, on the Générale des Carrières et des Mines au Zaïre (Gécamines), which therefore prevented it from reinvesting profits in its own businesses.

31 The industrial sector tended to be treated as a source of revenue which might be collected without difficulty or complaint. Multinationals did not always contest the more extreme demands of tax from officials while Congolese businessmen used to bargain with them.

32. A persistent problem with revenue collection was the low level of remuneration for officials and the rules by which they were required to raise a fixed amount of income from particular groups of companies, whatever their tax liabilities and financial resources. The collection of indirect taxes, principally levied on external trade by the customs and excise agency, OFIDA, had been governed by the same rules: officials negotiated with importers to reach private settlement. This combination of discretion and lack of transparency worked to the exclusion of the Treasury. The same maneuvers had been frequently done by the people working for the Service Nationale de Contribution, which, like OFIDA, could have provided the government with a large amount of money to finance essential state functions.

33. Thus bribery and corruption became pervasive and a necessity for engaging in private business. Those in charge of tax collection appropriated a large share of the potential revenue to themselves, as could be expected in a low population density country without a strong and disciplined bureaucracy, a transparent administration, and an efficient and credibile judiciary.

34. In addition, the public revenues which were collected under the Mobutu regime were dissipated into private consumption and wealth for Mobutu, his family, and those who held key offices within the state. A vast body of evidence suggests that Mobutu misappropriated several hundred million dollars annually that belonged to the national treasury. He and his family and associates misdirected up to 40 percent of the government capital budget. They used these funds for luxury consumption, for personal investment

\footnotetext{
${ }^{12}$ Thomas M. Callaghy, The State-Society Struggle. Zairre in Comparative Perspective, 25-26.
} 
abroad, payments to political allies to buy their allegiance, and for other activities which fall completely outside the scope of legitimate governance ${ }^{13}$.

35. Apart from potential and actual fiscal revenues there were three other financial flows that served to enrich Mobutu, his family and associates: 1) covert payments by foreign governments, including the United States, 2) diversion payments for mineral export, and 3) foreign aid and investment funds. Of these export revenues, the mineral industry provided the most important and reliable source of hard currency. Identifiable "leakage" often exceeded $\$ 100$ million per year. Mineral resources thus failed to be a process and an opportunity that could provide the government with revenues to finance essential state functions.

36. All past attempts by international financial organizations to "reform" the financial system and create an adequate revenue base in the country collided with personal and class interest, and they ended in utter failure. Perhaps the most serious of such efforts came during the Carter administration when-partly at the behest of the United States - the International Monetary Fund sent "Erwin Blumenthal, a senior banker, to monitor the Zairian Central Bank and promote financial integrity. Blumenthal soon left Zaire in frustration, declaring that the corrupt system in Zaïre with all its wicked manifestations, its chronic mismanagement and fraud would destroy all endeavors for change."

\section{Monopoly Over the Means of Coercion}

37. Presentation: A monopoly over means of coercion is part of most definitions of stable and development-oriented states. Morris Janowitch ${ }^{14}$ explains this reality when he writes that a stable and development-oriented state is a territorially based social system which monopolizes the use of instruments of violence and coercion for both internal and external objectives. It has the monopoly over means of coercion, enforces law, it establishes and maintains order within its territory, and protects life and property from threats, whether domestic or foreign in origin. It tries, through its army, to subordinate internal rivals and neighbors, and fight off more distant rivals.

38. The means of coercion may include actions, whether actual or threatened, public or secret, that cause loss or damage to persons or groups, or to their possessions. They also include facilities for incarceration, expropriation, humiliation, and publication of threats. Expenditure for the military and for other instruments of coercion usually requires a significant budget in a stable state. Conversely only the effective operation of an administrative and coercive apparatus can generate the necessary resources.

\footnotetext{
${ }^{13}$ Mondonga M. Mokoli, The Transition Towards Democracy in Post-1990 Zaire: Contradictions and Dilemma, (Bethesda, MD: International Scholars Publications, 1997), 122-123.

${ }^{14}$ Morris Janowitch, Political Conflict. Essays in Political Sociology, (Chicago: Quadrangle Books, 1970), 119.
} 
39. Of course, the monopoly over means of coercion is only a necessary, but not a sufficient condition to build a stable and a development-oriented state. No government can coerce all the people all the time. If rulers try to do so, they become wholly dependent upon the means of repression, and vulnerable to public protests, uprisings, and eventually a coup d'état. Rulers must be able to garner popular support through voluntary compliance and bargaining. Thus, a stable and development-oriented state deploys coercive means carefully and consistently, without abuse.

40. Application: Since its independence, the Democratic Republic of the Congo has not been, as Thomas M. Callaghy ${ }^{15}$ underlines, a case of military domination by a highly professional, bureaucratized, and developmentally oriented military. This partially accounts for the less well-developed repressive capability of the regimes in the Congo.

41. Nevertheless, the Mobutu regime had some monopoly over the means of coercion, especially during its first fifteen years. Indeed, it was the army, with the support of the Western powers, that constituted the original source of Mobutu's power and helped him take command of the country in 1965.

42. But Mobutu rendered that same army that brought him into power largely ineffective at home. He forced to flee and/or executed the few best educated officers who had their training either in Europe, in the USA or in Israel because he feared an eventual political competition with them. Most of the armed forces were often unpaid and did not have arms, ammunition or even uniforms. Those who were armed occasionally offered their protection service for a fee, acting as private militia and they had largely to go their own ways because of the lack of support from the central government in Kinshasa. They relied on shakedowns and on occasional looting to support themselves.

43. As a result, Mobutu created the Service for Action and Military Intelligence (Service d'Action et de Renseignements Militaires (SARM) and Division Spéciale Présidentielle (DSP) as his personal intelligence and guard that were drafted mainly from his Ngbadi and Ngbaka tribes. They were loyal only to him and his family, but were paid and armed out of state revenues. After a while, they also were affected and weakened by the mismanagement. During this process other competing sources of coercion not under state control, such as private militias, grew in influence for public and mostly for personal goals.

44. The Presidency therefore lost the monopoly over the means of coercion. It no longer maintained and managed the army, including its personal intelligence and guard, as well as other security services effectively, largely on account of the growing fiscal incapacity of the state.

45. Whenever Mobutu was under attack by insurgents, he had often to call on outsiders, such as Belgium, France, the United States, Israel, Morocco and Senegal, for help.

${ }^{15}$ Thomas M. Callaghy, The State-Society Struggle. Zaïre in Comparative Perspective, 24-25. 
However, such help was not forthcoming from these countries when his regime was under attack by the rebellion that eventually deposed him on May 17, 1997, and drove him into exile in Morocco, where he died on September 7, 1997. Military agreements between the Congo and Western powers were suspended earlier as the latter withdrew their backing of the Mobutu regime after the end of the Cold War.

46. The judicial system, also a means of coercion, was completely corrupt and inefficient. Those who had money and/or political influence were above the law.

\section{Transparent Administration and Professional Bureaucracy}

47. Presentation: A transparent administration and a professional bureaucracy are consistent with a stable and development-oriented state and they must be sustained. Administration is, as Alan Jensen ${ }^{16}$ notes, the product of rational construction; it pursues organizational goals within the limits of the rules that are linked in a consistent body of law, and they do not contradict each other. These rules, or legal norms, are established on the grounds of expediency (usually called "operating procedures") and rational values. This is true also for each individual who administers his office in the organization or government. Each member is expected to obey these rules.

48. The wide variation in the quality of state formation depends, as Thomas Callaghy argues, among others, on discipline, competence and accountability of the bureaucracy. Efficient bureaucracy strengthens the administration and the management of the government and it increases the decentralizing role of the state, the private sector, non-governmental organizations, and other community-based organizations of civil society in the political economy of the country.

49. In a similar vein, Stephen Haggard and Steven B. Webb ${ }^{17}$ present a series of organizational, administrative, managerial and ethical factors that contribute to the governmental administration's ability to function well. Among them are the efficiency with which information is collected and shared, decision-making is organized and decentralized, and tasks are allocated to different services; the accountability of personnel; and the integrity and transparency of the financial workings of government, and review functions.

50. Application: Sizable and professional administrative and technocrat groups, both civilian and military, have not developed in the Congo and merit-based personnel rules have been circumvented. Thomas M. Callaghy ${ }^{18}$ notes that this, in large part, accounts for the much less developed social and economic planning and implementation capabilities and for a more personal approach to politics and policy making. The administration is not

\footnotetext{
${ }^{16}$ Alan F. Jensen, Sociology: Concepts and Concerns, (USA: Rand McNally, 1971), 92-97.

${ }^{17}$ Stephan Hagard and Steven B. Webb, "What Do We Know About the Political Economy of Reform?" in The World Bank Research Observer, volume 8, no. 2, July 1993, pp. 143-168.

${ }^{18}$ Thomas M. Callaghy, The State-Society Struggle. Zaïre in Comparative Perspective, 24-31.
} 
bureaucratized, functionally differentiated, technically oriented, effective, nor accountable; rather, it is (neo-) patrimonial.

51. A main characteristic of that patrimonial administration and bureaucracy was the predominance of a single ruler, the President, and a small group in which he granted power, privilege, and material goods to clients or subjects in return for acknowledged authority, support, loyalty, deference, and obedience. This pattern was replicated downward through a complex and often shifting patron-client system. Tribal affiliation, ethnicity, and personal loyalty were among the main criteria in hiring and firing people. The president at the top of this apex of political relations was the "modern equivalent of the traditional patrimonial leader".

52. That patrimonial mode of governance, where public offices were appropriated by personal and social groups and their benefits used to feed patronage networks and personal fortunes, undermined the managerial rationality, predictability and accountability. It also undermined governmental organizations, the domestic capacity to maintain order and to formulate and implement policy changes. The administration and the bureaucracy were opaque, inefficient, over-staffed, corrupt, and unaccountable. Those in charge systematically extracted rents from their clients and the public. The following government services were among the most threatening for the people and the businessmen: Army and Garde-Civile (Police), Service National d'Immigration (National Service of Immigration), Office des Douanes et Assises (Customs), and Office Zairois de Commerce (OZAC).

53. Winsome J. Leslie ${ }^{19}$ rightfully observed that in an effort to consolidate his power and increase the vulnerability of administratives, bureaucrats, government officials and army officers, Mobutu used the tactic of frequently rotating them. That hampered the sense of administrative and bureaucratic continuity, for example, in terms of reforms that the World Bank and other donors supported. Often, those civil servants were reluctant to make policy decisions or to enforce changes based on the World Bank recommendations for fear of losing favor with Mobutu.

54. Thus the rise of a transparent administration and a professional bureaucracy was undermined in the Congo. Their failure in delivering services, for instance, should not be surprising, considering the fact that delivery is based on an organizational model which assumes that major decisions should be centrally based. Far removed from the people and their needs, the delivery was implemented through structures intended to be more responsive to central direction than local reality.

\section{Ability to Ensure Food Supply}

55. Presentation: A stable and development-oriented state must be able to ensure food supply to its people, in both the rural areas and the urban areas, but especially the latter. Food

\footnotetext{
${ }^{19}$ Winsome J. Leslie, The World Bank \& Structural Transformation in Developing Countries. The Case of Zaïre, 68-75.
} 
supply difficulties and crises, whatever their origins, are serious threats to any government or ruler. It is for this reason that agricultural and food policy matters are so highly politicized, and that states have so often intervened heavily in production, distribution and allocation of food.

56. Michael Lofchie ${ }^{20}$ correctly discusses this problem with regard to Africa when he writes that Africa's agrarian collapse is at the basis of a widespread breakdown of political legitimacy and loss of social trust. Governments that cannot provide an adequate supply of reasonably priced foodstuffs to their urban populations have experienced sharp increases in public opposition, manifested most dramatically in the high incidence of food riots in many capital cities, such as Tunis, Monronvia, Lusaka, Khartoum, and Nairobi. The collapse of at least two of these governments, Liberia and Sudan, was rooted partially in sudden price increases for food staples.

57. Although the widespread loss of public trust in African governments is the outcome of a complex assortment of political and economic factors, none has as direct a bearing on popular attitudes towards government as the effectiveness of national political leaders in managing their country's food systems.

58. Application: Due to the lack of a coherent and sustainable national development policy in general and a bad rural and agricultural policy in particular since independence, the Democratic Republic of the Congo has destroyed its agricultural capabilities and its ability to ensure food supply to its people. That situation has worsened since the Second Republic and it has resulted in poor nutrition and bad health, premature deaths, low growth productivity, and strikes in the Congo.

59. Mobutu, with substantial assistance and encouragement from Western donors, governments and agencies, made the agricultural sector the "priority of priorities" to achieve self-sufficiency in foodstuffs and to reach the pre-independence level of industrial crop production and export. The Department of Agriculture and Rural Development was created to establish policy regarding the pricing, marketing and storage of agricultural crops, assisting organizations under its control, supporting the operation of an adequate extension service, and carrying out agricultural research on all crops ${ }^{21}$.

60. The rationale for the priority that appeared to be given to the agricultural sector was that "the majority of the population lives in rural areas. Agriculture would provide people with jobs and improve their living conditions. It would provide the state with foreign currencies and a principal tax base from which to draw government revenues. The

\footnotetext{
${ }^{20}$ Michael Lofchie, et al, Africa's Agrarian Crisis. The Roots of Famine, (Boulder, Colorado: Lynne Rienner Publishers, 1986), 4-5.

${ }^{21}$ Mondonga M. Mokoli, State Against Development: The Experience of Post-1965 Zaïre, (Westport, CT.: Greenwood Press, 1992), 10-11.
} 
agricultural sector offers the major source of saving for non-agricultural investment, and because of agriculture, Zaïre would become self-sufficient in food ${ }^{22}$."

61. Large-scale rural and agricultural development projects and programs were designed and implemented. They were mostly implemented in Shaba and other regions which were harboring political opposition to Mobutu, as well as in the native villages of the most influential political and military leaders. Funding for the financial execution of these large scale projects and programs relied on the assistance of international organizations and bilateral aid ${ }^{23}$.

62. However, such expenditures, though related to agriculture increasingly were channelled through by agencies other than the Ministry of Agriculture. Total public sector expenditure for agriculture declined to around 4-6 percent of aggregate expenditure. The Office of the President (Présidence de la République) itself maintained a number of agricultural advisors, and also carried out important programs and projects which were selected and budgeted through the Office rather than through the Ministry of Agriculture. Yet the Office of the President was also characterized by mismanagement and the lack of a follow-up.

63. The state had lost its ability to ensure food supplies to its increasing population and that resulted in stagnation, and in many cases a decline, of agricultural production, a shrinkage of the percentage of the active population involved in agriculture, as well as the hyper-dependency of the state on imports of food. Also, the state no longer had revenues nor foreign assistance to import food; meanwhile, the purchasing power of average people had become too weak to afford the cost of imported food.

\section{Representative Institutions to Ensure Accountability}

64. Presentation: Taxation, coercive and bureaucratic powers are likely to be abused if not checked by institutions which represent the populations which are subject to the powers of the state. As European history and the recent history of decolonization show, representative institutions cannot simply be imported or imposed from above. Such institutions have to emerge slowly over time, as a consequence of struggle and bargaining between rulers and vocal sectors of the ruled populations. The emergence of these institutions can be also facilitated by external financial support.

65. Application: The Democratic Republic of the Congo has been characterized by the absence of representative institutions to ensure accountability. That is due to the fact that since independence, and even prior to that, the Congo has not had classes or social groups which could have provided integrating and modernizing forces in the country, and have

\footnotetext{
${ }^{22}$ Mondonga M. Mokoli, State Against Development: The Experience of Post-1965 Zaïre, 11.

${ }^{23}$ Interview du Président Mobutu," in Le Courrier-Afrique-Caraibes-Pacifiques-Communauté-Européenne, no. 78 , mars-avril 1983,33 .
} 
taken an independent stance in bargaining with other groups about representative institutions, and make them work. After independence, the Congo had no domestic private sector, no capitalist class, no workers or farmers organizations, no bureaucracy, nor did it have a nationally organized independence movement with organizational capacity and experience. Even the church was not a home grown institution; local church initiatives were stifled by the Belgian colonizers.

66. In addition, mineral wealth was highly concentrated in few regions. It is thus no accident that the new country was immediately subject to centrifugal forces, which led to unrest and revolts. The army was the only organization with a national base, but it stepped into the void with a coup which brought Mobutu to power.

67. Without social groups with the economic power and/or national organization Mobutu had no building blocks for a state, nor effective counterweights to personal rule. Instead, he had to contend in the sparsely populated country with a myriad of conflicting regional, local and tribal social groupings which he needed either to co-opt, dominate, or suppress.

68. Mobutu quickly established a military dictatorship through the Mouvement Populaire de la Révolution (MPR) that became the state-party and it carried out the functions that were traditionally reserved to the state. He moved from a federal structure, that was built during the First Republic and gave considerable power to the provinces, to a unitary system with an over-centralized government.

69. The MPR's territorial organization had followed the administrative structure of regional government, and government administrators had to fill dual roles in the state and in the party. Trusted individuals were posted to regional administrations, and served at the discretion of the president, and therefore were not able to build up independent regional power base. Even the army became a part of the Mouvement Populaire de la Révolution, but it did not rule the country. Mobutu sought to keep it (army) out of politics, broadening his base of power beyond the army while using it as an instrument of repression. That overall political maneuver undermined the emergence of representative institutions that could ensure accountability in the Congo.

\section{Bargaining Among Equally Powerful Groups}

70. Presentation: Bargaining is, in the state formation, a "prime mover" process that enables the passage of a growth-oriented state to a non-coercive and development-oriented state. It is, as Lewis A. Froman, $\mathrm{Jr}^{24}$ explains, a type of political decision-making and a major component of politics. It occurs in democratic and non-democratic settings.

\footnotetext{
${ }^{24}$ Lewis A. Froman, People and Politics. An Analysis of the American Political System, (Englewood Cliffs, N.J.: Prentice-Hall, 1962), 53-78
} 
71. The critical issues in bargaining are some balance of power among groups, full knowledge by all about policy and program costs and consequences, and a well known, common state budget constraint. Barrington Moore, $\mathrm{Jr} .^{25}$ points out that the success of bargaining depends, among others, on the individuals, i.e., elites, who have vision, commitment, will power, moral conviction, and a sense of responsibility, as well as their wisdom and efforts to lead the country to a new and better way.

72. Gary S. Becker ${ }^{26}$ has also investigated this issue of bargaining. The conclusions that he has reached are that bargaining among interest groups is likely to lead to efficiencyenhancing outcomes if:

(a) Interest groups have equal ability to exercise political pressure;

(b) They know the economic consequences of the policies and programs that are the object of the bargaining;

(c) They face a common budget constraint; and

(d) Some other regularity conditions are satisfied.

73. The intuition behind this is as follows: If interest group A wants to obtain a special benefit to be financed out of a common budget constraints, for example, a program which improves its economic situation, interest group $\mathrm{B}$ and $\mathrm{C}$ will not agree to the program, unless that program raises output and growth sufficiently to make them at least as well off (after taxes), as without the program. If, on the other hand, the program does not draw resources from the common budget constraint, or its costs are not transparent, groups B and C will not spend time and energies lobbying resources or political capital to defeat the proposal.

74. Thus one group will not let the other group(s) enact a policy unless it is assured that it also will gain from it. Groups, such as poor peasants, which are not represented adequately in the bargaining process are likely to bear the brunt of taxation. A bargaining equilibrium among powerful groups which does not include poor populations or peasants may still lead to efficient policies and programs, just as long as it fulfills the condition that the resulting growth makes those who participate better off than they would be in the absence of the policies and programs. But members of a coalition supporting a bargaining equilibrium will shift taxation to the left-out groups. Under full information about policy impact this tendency to tax left-out groups is only restrained by the adverse impact of excessive taxation of the left-out groups on investment and growth, and therefore on the sustainability of the tax base.

\footnotetext{
${ }^{25}$ Barrington Moore, Jr., Social Origins of Dictatorship and Democracy. Lord and Peasant in the making of the Modern World, 198.

${ }^{26}$ Gary S. Becker, "A Theory of Competition Among Pressure Groups for Political Influence," Quarterly Journal of Economics, vol. 98, no. 3, (1983), 371-400
} 
75. The emphasis in bargaining is on conflict resolution and the distribution of material advantages. Bargaining can create numerous new claims on the state: power sharing, efficient judiciary, and cooperation in state development programs such as taxes to raise state revenue, pension, payments to the poor, public education, health, city planning, rural and agricultural development, environment, and much more.

76. In his investigation of state formation in Europe, Charles Tilly ${ }^{27}$ shows that representative institutions emerged as a consequence of bargaining between rulers and the ruled and they resulted in bargaining for revenues, for the means of waging war, for efficient judiciary, for the monopoly over coercive means, etc. Such bargaining rested on the existence of powerful groups on which the ruler, or the state, depended and which could withhold financial or other support to the state. During crises, often fiscal crises brought about by warfare, rulers were forced to create representative institutions such as parliaments and courts which curtailed their arbitrary powers.

77. Tilly emphasizes that the creation of non-coercive states via such bargaining processes has been much easier in areas where there are high population density, and where there is a concentration of capital associated with trade and manufacturing. On the one hand, a strategy relying on coercion and arbitrary rule drives away trade and discourages manufacturing. As the state becomes increasingly dependent on revenues from individual entrepreneurs making decentralized decisions in increasingly integrated international financial markets, it becomes necessary for rulers to adopt growth-increasing policies. On the other hand, trading and manufacturing elites are in a position to provide, or withhold the financial means on which a stable state depends. Free market and representative institutions are strongly linked by this interactive process.

78. Application: All the attempts to generate bargaining equilibria failed in the Congo. The Mobutu regime successfully undermined the rise of competing groups, which would have given shape, coherence and discipline to the state and made it an engine for sustainable development. The leaders or elites were, and have remained, poor, without any substantial fiscal means, they have been fragmented, and more characterized by ethnic consciousness rather than class or professional consciousness.

79. Mobutu rather tried to create an aristocratic class composed of his close political supporters, including army generals, who depended upon him for their socio-economic and political status and welfare. The opposition in Zaïre was mostly composed of individuals who were financially weak and who had worked for Mobutu for years as the engineers and architects of the Mouvement Populaire de la Révolution, the "state-party." They pretended to be his opponents only whenever Mobutu shuffled them out of office either for strategic or tactical reasons, but they became his major supporters whenever he re-appointed them. Even the creation and the functioning of most of the so-called political parties of the opposition in Zaïre were funded by Mobutu and his associates.

${ }^{27}$ Charles Tilly, Coercion, Capital, and European States, AD 990-1990, 1-225. 
80. Nevertheless, in the face of mounting popular pressure for democracy Mobutu conceded in October of 1989 to the convening of "Popular Consultation" (Consultation Populaire) that led him to announce a limited transition to "three-party" democracy on April 24,1990 , and later to seemingly open the country to an integral multipartism.

81. The population rallied together to demand a Sovereign National Conference as a democratic settlement of all relevant social forces of the nation designed to take stock of what had gone wrong in the past and to chart a new course for a better future in all sectors of the society. However, Mobutu hardly complied with that demand; he significantly diluted the power of that settlement by creating another body of 738 members, with a large majority of individuals whom he appointed himself.

82. The Sovereign National Conference then became the High Council of the RepublicTransitional Parliament (Haut Conseil de la République-Parlement de transition), HCR-PT, henceforth Transitional Parliament). It debated, in different ad hoc commissions, the political and socio economic history and the future of the country and drafted the texts that were to guide the transition to democracy. These texts were rejected by Mobutu and his supporters.

83. The Sovereign National Conference thus failed to reach its initial goal of deciding the fate of the country because the conditions for bargaining equilibria in that settlement were not met. There were no independent elite groups with bargaining power. The delegates were, and have remained, fragmented, poorly organized, with no fiscal means, and the few people who had some bargaining power were Mobutu's allies, or co-opted by him. The Sovereign National Conference rather became a settlement through which Mobutu attempted to re-organize his falling regime in order to sustain the status quo.

84. Nevertheless, that conference enabled the people of the Congo to critically examine their social, political and economic problems, as well as identify their causes. Congolese made suggestions and recommendations for a better future. The Sovereign National Conference was, and remains, the only basis for the transition which has widespread legitimacy within the population in the Congo.

\section{Overall Assessment}

85. The historical and material prerequisites and processes discussed above have led to the formation of stable growth-oriented and development-oriented states in other environments. These conditions and processes are most likely to be found in capital-intensive societies, which obtain the bulk of their revenues from taxes on non agricultural production, income and trade, and achieve a relatively high degree of independence from agricultural and landlord interests. A high population density, with a concentration of population in cities, facilitated the collection of taxes and the maintenance of law and order, and have made it easier for populations to organize and seek political representation and accountability mechanisms. 
86. In the Congo, however, most of these prerequisites were unmet and their processes were politically distorted. The Mobutu regime failed to provide the appropriate conditions for the emergence of a development-oriented state partly because of its own incoherence, indiscipline and incompetence. Mobutu presided over a political system that had the formal trappings of a republic, yet it was the personal domain of the president. He refused to share power, he used the national treasury as his personal checkbook, and he undermined the rise of competing groups and representative institutions.

87. Nevertheless, Mobutu did not do what he did out of the blue; he himself responded to the impossibilities associated with the historical and material legacy of the Belgian colonialism that are spelled out in the Annex. As a consequence, the Congo has not made any progress in the formation of a growth-oriented state that could lead to the emergence of a stable and development-oriented state. This is the challenge that President Kabila is currently facing.

\section{The CURRENT Situation}

\section{Positive Features}

88. The Democratic Republic of the Congo, under the current regime of Laurent D. Kabila, has some positive features that deserve consideration and on which one can build in the process of the formation of a stable and development-oriented state. These features include:

- The people of Congo are aware of the profound crisis that they have been experiencing for decades. They are looking for radical and durable solutions to their suffering. This has been evidenced by strikes, demonstrations, the creation of NGOs and the informal sector, emergence of political parties, the Sovereign National Conference, and the Congolese's repeated demands to the current regime to undertake sound economic and political reforms.

- Congo has considerable development potential: the natural resources are immense and their development would allow the reconstruction of a stable revenue base for a state.

- There is a group of entrepreneurs interested in private economic development who have survived by "hiding" in the informal sector. Under the right conditions they could develop into a powerful private sector able to counteract the arbitrary powers of the state.

- Congo has under-used its agricultural resources, and has peasants and traders who could ensure food supply both in the rural areas and in cities, if the regime 
provides them with freedom to produce and trade under a positive incentive regime. If assisted to organize they could emerge as an independent bargaining force.

- A vocal civil society could become the basis for a powerful group that could exercise bargaining power in the Congo.

- The current regime is trying to draw technical expertise from expatriate nationals to build an efficient administration and bureaucracy.

- The people of the Congo have acquired some sense of national identity and most of them do not want to see their country torn part again as during the First Republic. Ethnic and regional solidarity have, in many cases, prevented social dislocation in urban areas in the Congo. Its cultural diversity is also a source of wealth.

89. However, there are also serious obstacles to a successful process of a developmentoriented state in the Congo.

\section{Obstacles}

- The Congo has many material features which have characterized coercionintensive societies. These include low population density, poor infrastructure, potential economic dominance of the mining sector (with the concomitant opportunities for rent dissipation), an underdeveloped private sector which is poorly integrated into the international economic system, an impoverished and suppressed peasantry, continuing tribal rebellions in the east and the west, and secession tendencies in the south spurred by the recent currency change.

- The current regime has not fully established and developed the monopoly over the means of coercion, and this has been a source of instability and arbitrariness. Police forces are not under the full control of the regime and there is no adequate functioning court system to re-enforce order and security. The forces from Mobutu's previous army and rebel groups are not under the regime's full control, and they constitute a threat not only to the current regime but also to the civilians both in cities and in rural areas.

- There are no truly national pressure groups with common economic interests, which can challenge political decisions on professional or technical grounds. The most powerful social formations are of tribal, regional and local origin, and have little potential to act as integrating forces, but rather represent major risks to national unity. The vocal elites in the Congo are in short supply, poor, disorganized, fragmented, tribally and ethnically oriented, and easily manipulated as evidenced during the Mobutu regime (see the failed Sovereign National Conference) and during the current regime, as well. They lack vision and 
commitment, and are unable not only to seize opportunities as they appear, but also to create them, by identifying and reaching out to potential beneficiaries, reshaping institutions, and articulating a compelling and achievable vision for the future.

- Low productivity, unequal distribution of resources, and the lack of bargaining among social groups are among the factors that are likely to trigger ethnic conflicts and violence.

- The remnants of the parastatal sector contain many organizational residues which continue to function as fiefdoms, or which could reassert political power under an economic recovery.

- The administrative and bureaucratic apparatus is still patrimonial, centralized, badly coordinated, little motivated, and poorly qualified. There are virtually no accountability mechanisms. The regime has not stipulated clear policy on important issue of citizenship to end the confusion that has been taking place in this matter, especially in the eastern part of the country.

- Revenue shortfalls continue to squeeze both salaries and the supply of essential inputs into the administration. There is no operating budget and public servants remain unpaid and/or underpaid. The new currency of the Franc Congolese, introduced on June 30,1998, is supported neither by a sustainable economic growth nor by a political consensus.

- There are huge foreign and domestic debts which remain largely unserviced, but which represent early potential claims on state revenues. Yet the current regime fails to consider international organizations, aid agencies and foreign governments as sources of development assistance that are willing to help create and jump-start the prerequisites for the formation of a stable and developmentoriented state in the Congo.

90. In summary, the state in the Democratic Republic of the Congo has virtually no tax base, weak revenue generating apparatus other than for mining revenues, very limited monopoly over the means of coercion and no efficient judiciary system, no professional bureaucracy and transparent administration, and no ability to ensure the food supply to the population. It lacks powerful nationally integrated interest groups, strong bargaining partners, representative institutions, accountability mechanisms and a consensus on the country's organizing principles, as well. The current regime needs to increase its understanding of the wider world in order to benefit from it through trade and cooperation.

\section{IMPLiCATIONS FOR DEVELOPMENT STRATEGY IN THE CONGo}

91. Major obstacles face the process of the creation of the prerequisites for the formation of a development-oriented state in the Congo. These obstacles are 
counterbalanced by only a few positive features on which to build. But continuation of the profound crisis in the Congo has enormous human costs. Therefore, a strategy needs to be developed and implemented which addresses the fundamental constraints to the formation of a growth development-oriented state that leads to political decisions that support widely shared growth, with improvements in the welfare of all social groups, especially the poor.

92. Such a strategy has to have as its basis social peace (notably in view of the current renewed civil war), free market economic development in the cities and the countryside, decentralization of government to regional and local levels, and the strengthening of civil society organizations capable of acting at local, regional and national levels.

Representative institutions and accountability mechanisms are essential at all levels, but they will not function properly unless economic and social development leads to the creation of the independent pressure groups which can counterbalance the coercive tendencies of the state implied in the existing material, economic, and social conditions, and which can check each other's tendency to accumulate and misuse power.

93. The following priorities, many of which we already stated, emerge from this analysis:

1. Reorganization of the national armed forces and the police to recreate the state's monopoly over the means of coercion, peace and guarantee for physical safety and personal property.

2. Dismantle structures and policies which stand in the way of the development of independent forces and eliminate illegal sources of "taxation" over production and trade. This includes privatizing and/or dismantling existing and potential fiefdoms in the parastatal sector, dismantling central bureaucracies whose functions should be transferred to local and regional governments, and elimination of statutory or de facto regulations and monopolies which inhibit capitalistic production, trade, domestic and foreign investment. Particular attention will have to be given to dismantling possible fiefdoms and regional power bases in the mining sector and its parastatals.

3. For the widely dispersed agricultural sector, dismantling of monopolies and anticompetitive policies and regulations is particularly important since the imposition of local monopolies and constraints to competition is particularly easy in low population density areas. This first step to a coherent agricultural strategy would quickly ensure an adequate and cheap supply of food to rural and urban markets, as well as contribute to a revival of private investment, rural growth, and the concomitant development of independent pressure groups.

4. Create an apparatus which is capable of mobilizing revenues which can be used for financing essential state functions and development programs. Of particular importance here are the development of transparent mining and deforestation/reforestation policies which ensure that the rents are captured and 
deployed for development purposes, rather than dissipated for other purposes before they ever reach the state. Such policies need to ensure investment incentives for domestic and foreign investors and transparent allocation and accountability mechanisms. They will also prevent the destruction of forests and the desertification of the environment.

5. Reorganize the central state to concentrate on the essential remaining functions, and build the bureaucratic apparatus and incentives within which a small professional administration can emerge. The small administration, bureaucratic, and judiciary apparatuses must be run by disciplined and competent individuals. Their recruitment from inside the country and among the expatriate community must be done based on their education, accomplishments and experience rather than based on paternalistic and clientelistic goals.

6. Build up a professional judiciary to enforce the law and establish order.

7. Strengthen civil society at central, regional and local levels by enabling legislation and by letting it participate fully in economic development programs and political processes. Particular assistance should be given to help organize the impoverished peasants and other poor rural and urban groups so that they can effectively participate in bargaining and prevent the placing of excessive burdens of taxation on them.

8. Strengthen the state at regional and local levels and create transparent and predictable intergovernmental fiscal arrangements for revenue sharing. This implies the rapid transfer of power and revenue authority of the central state to regional, and especially local levels and the creation of the regional and local representative governments to improve accountability over the resources.

9. Initiate the creation of representative institutions at the level of the central state, by building on the best elements of the Sovereign National Conference, which set the foundations for the Third Republic in the Congo.

10. Contribute to the establishment of institutional mechanisms and arrangements that can ensure a fair distribution of public amenities.

11. Rehabilitate and develop the inter-regional and rural infrastructure which is needed to integrate national markets and market-oriented peasant and plantation sectors.

12. Finance basic literacy training and primary education as an essential precondition for effective organization and participation of poor populations in economic development and political processes. 
94. In order to start on these pressing programs, the regime needs access to fiscal resources. Tight and transparent control over mining, logging and customs revenues will not suffice to fund the priority actions and service the debt overhang, even if the tax and tariff rates are set at levels which encourage investment and trade. Not only are revenues required for reforming and operating the means of coercion, and for financing decentralized development programs, but also for downsizing and dismantling the parastatal sector and the bureaucracy.

95. Therefore, the government will have to gain access to substantial resources from the foreign lenders and donors, to whom it needs to be able to present clear and coherent agenda and strategy. They, in turn, must focus on the entire process of the formation of a development-oriented state, rather than on debt collection.

96. It is worth underlining here that no government, no matter how well intentioned, informed organized or charismatic will be able to overcome the extraordinarily adverse initial conditions for the formation of stable and development-oriented state in the Congo without alliance with external partners. These partners can provide finance and advice, and help strengthen the bargaining power of the few constructive forces inside the Congo.

\section{IMPLICATIONS FOR EXTERNAL SUPPORT AND THE WORLD BANK GROUP}

97. Presentation: Crises in general and the fiscal crises of states in particular provide a fertile arena for contestation and violent defiance of the state, expose the ruling group and they can, if they persist, result in the collapse of a political regime. Also, fiscal crises of states constitute a motive and an opportunity that can attract external support.

98. The ability of a country to receive external support does not solely depend on its fiscal crisis per se. It rather depends mostly on the capacity and commitment of the government of that country to initiate and systematically implement sound economic and political reforms and work with external and internal financiers, governments and international organizations as partners in order to help jump-start and speed up the process of reaching the stage of selfsustaining growth.

99. Reforms provide any group, external and/or internal, which is in a position to give or lend resources to the state (financial, military assistance and arms, food resources, and ideas), with a disproportionate influence over the policy outcome. Thus reform outcome is likely to reflect the policy preferences of those well endowed groups. Whether such influence is a good thing or detrimental depends on the motives and wisdom of those groups, as well as the power of competing groups. During the Cold War, for instance, bi-lateral assistance was primarily used to purchase ideological loyalty, contributed little to development, and undermined incipient independent interest groups. With the end of the Cold War, conditions for a position role of external donors have significantly improved. 
100. In general multilateral lending institutions understand very well the leverage provided by fiscal crisis. They quickly responded to the opportunities to influence reform efforts triggered by the fiscal and debt crisis of the early 1980s. They designed quick disbursing loans tied to policy conditions, and more recently attached strong conditionalities to debt reduction initiatives. They have developed strong collaborative links with bilateral donors and private lenders in these processes to ensure that assistance supports coherent and well-contested policies and strengthens the overall framework of incentives within and outside the state.

101. External lenders have focused initially on restoring macro-economic stability and the fiscal balance. They have progressively extended their policy dialogue and conditionalities to other essential conditions for growth, such as structural reforms which strengthen incentives for investment and capitalistic growth, and a broad array of institutional reforms in financial and real sectors of the economy. In these sectoral reforms they initially tried to streamline and strengthen sectoral bureaucracies.

102. But they quickly found sectoral reforms inadequate and are now working on much broader programs for public sector reform. Such reforms are pursued under adjustment loans as well as investment loans. The gradual move to consider judicial reform, governance and corruption issues indicates an increasing awareness of the importance of the prerequisites for a stable and development-oriented state. Yet these efforts have not yet been cast into an analytical framework of state formation; and given the full coherence coming from the deep understanding offered by such a perspective.

103. However, external influence has major limits. External financial institutions and donors face unusual difficulties when they decide to become engaged in a country with a poorly functioning state. They cannot and should not be expected to replace absent state capability.

104. External actors have also become acutely aware of the need for "ownership" of the reform programs that they support.

105. While external actors -especially during the fiscal crises- can help initiate reforms, any substantial success in this endeavor rests primarily on the shoulders of the leaders and citizens of the country that they are trying to help. Only with "ownership" will the governments be able and willing to carry out the agreed-upon reforms. But the sustainability problem persists long beyond the contractual loan periods. Only if a sufficiently powerful post-reform coalition emerges which has a stake in maintaining the reforms, i.e. "owns" the reforms, will they be sustainable, rather than undermined by backsliding or outright reversals. Only if a stable bargaining equilibrium among powerful forces supports the reform will this be the case.

106. Application: The enormous obstacles to the emergence of the prerequisites for a development-oriented state in the Congo confirm the fact that no government would be able to design, implement and finance a strategic development program without significant and coordinated finance and other support from the international community. The interest groups which could support an autonomous and stable, development-oriented coalition in the Congo are simply too weak or even non-existent. 
107. These weak interest groups need external allies to assist them in adopting and implementing strategies which would strengthen these autonomous forces and eventually the state. They badly need them in order to help create the prerequisites for a stable and development-oriented state, thereby assisting the jump-start and the acceleration of growth until the process becomes self-sustaining.

108. Many external institutions and donors have progressively introduced into their programs elements which are consistent with supporting the formation of a developmentoriented state. In particular, the emphasis on macro-economic stability based on sound fiscal and expenditure policies, favoring the insertion of the private sector into the global economic system, rural development, decentralization and participation are fully consistent with the strategic priorities listed above. Yet it is doubtful that these instruments will be used in a consistent manner without further increasing the focus of external assistance on helping create the essential conditions for a stable state.

109. Two processes of consultation have already been initiated. The first is the dialogue and the support to analysis and consensus building with the government of the Congo. The second is the coordination among the external agencies. These processes could benefit from a closer attention to the essential strategic priorities discussed in this paper.

110. External organizations need to emphasize jointly the importance of building a stable and development-oriented state through a consensus based on bargaining with a broad array of political formations, the private sector, regional and local interests, and nongovernmental and community-based organizations.

\section{If the government can be convinced to pursue a strategy which incorporates the} essential components of a development-oriented state, and if it initiates consistent steps to implement it, significant financing requirements will have to be met. They arise in four areas: financing of essential functions of the central state finances of regional and local governments; financing to strengthen the emerging private sector; and financing of development programs via community-based institutions and organizations.

112. Financing for the central state will have to include support for privatization and dismantling of the potential fiefdoms in the government, and the parastatal sector, including relocation and severance pay. It also includes the necessary finances to establish the monopoly over means of coercion, and of an independent judiciary. Financing for the private sector and local and regional government will have to go directly to them, bypassing higher level governments. And financing of community actions and NGO activities needs to bypass the government altogether, with the possible exception of some coordination by local councils. Thus external support in general and the financial assistance in particular should be offered whenever there is a reasonable assurance that they will be used effectively.

113. External financiers need to recognize the futility of their past reliance on formal accounting and procurement procedures to ensure proper use of money. Moreover, it is 
likely that the conditions which led to its ineffectiveness in the past have worsened since the withdrawal of the agencies from the Congo. This focus does not address financial control over the government's own resources. Instead the focus needs to be on a careful design of the money flows so that they can reach the intended beneficiaries as directly as possible. They need to be designed to strengthen accountability to the beneficiaries themselves, their local organizations, and local and regional politicians, as well as accountability via the press and rival interest groups.

114. For the World Bank Group in particular, the present analysis points to the paucity of instruments which it has to support the creation of prerequisites to build a stable and development-oriented state in the Congo. In the short run, its most potent tools are knowledge, lessons from other countries and non-lending services. The World Bank Group therefore has a compelling need for coordination and partnership with other external agencies. 


\section{ANNEX - Historical BACKground of THE CONGo}

With an area of 2,344, 885 square $\mathrm{km}(905,365$ square miles), the Democratic Republic of the Congo is one of the largest countries of sub-Saharan Africa. It is often called the "heart" of Africa because of its strategic location in the center of the African continent.

Congo's population is approximately 45 million and, with the exceptions of some regions, population density remains low. Congo is three times bigger than the state of Texas in the United States, and eighty times bigger than the Kingdom of Belgium that owned it for about a century. The Congo has about 450 tribes and 250 dialects. Before colonization, several of the numerous tribes and ethnic groups were organized in independent kingdoms and state-like societies. Low density and high diversity of populations create significant challenges for state formation.

The natural resources of Congo are potentially immense. The climate is favorable to profitable agriculture, the network of waterways is naturally navigable, there is mineral wealth in copper, tin, silver, uranium, cobalt, manganese, malachite, tungsten, diamonds, iron, bauxite, and gold. Copper and diamonds are the most important mineral sources; copper, for instance, accounts for about six percent of the world's production ${ }^{28}$.

In 1876 the Association Internationale du Congo, headed by the Belgian monarch, King Leopold II, began to establish trading posts along the River Congo. These kingdoms and state-like societies were recognized by other colonial powers from 1884 as the Congo Free State, which became a Belgian colony in $1908^{29}$ in reaction to the abuses being practiced by Leopold's authorities

It is traditional, as Crawford Young ${ }^{30}$ indicates, to analyze the colonial structure in the Belgian Congo in terms of a trinity composed of the administration, church, and large enterprises. On the administration side, as early as the 1920 s the density of administration in the Congo was unequaled in Africa, with the significant exceptions of Mauritania and Dahomey, the current Benin. By the time of independence, there were 10,000 Belgian civil servants and officers in the administration, magistrature, and army. No Congolese, rural or urban, could have failed to perceive that he or she was being administered.

As far as the churches were concerned, one could not fail to be impressed by the scope of the evangelical effort in the Congo. In 1958, it was estimated that the Congo

\footnotetext{
${ }^{28}$ Sandra W. Meditz and Tim Merrill (eds), Area Handbook: Zaïre: A Country Study, (Washington, D.C.: Headquarters, Department of the Army, 1994), xxxv-325.

${ }^{29}$ Country Profile: Zaîre, (London: The Economist Intelligence Unit, 1996-1997), 3.

${ }^{30}$ Crawford Young, Politics in the Congo. Decolonization and Independence, (Princeton, N.J.: Princeton University Press, 1965), 64-66.
} 
counted 5,371,785 Christians, 80 percent of whom were Roman Catholics. The Protestants were always outsiders. With the exception of one small Belgian group, the missionary force was composed of British, American, and Scandinavian nationals, whose loyalty to the Belgian colonial enterprise was somewhat suspect. Although Belgian administrators were far from unanimous in their own religious attitudes, the Belgian administration itself was strongly committed to evangelization as an integral part of its objective.

The final element in the trinity of power, the large companies, was no less remarkable in the scale of its operation. In part these companies were a survival of the concessionary regime by which King Leopold II sought quickly to make effective the occupation of the company by the Free State or by its surrogates. The colonial administration was expected to give full support to the companies in recruiting labor and seeing that food was produced for the labor camps.

Although the tripartite alliance tended to display a monolithic face to the external world and to the Congolese, it would be misleading to underestimate the continual bargaining and dialogue that went on among them. Their interests were not in fact the same: the administration was, in the final analysis, most concerned with an effective scheme for governing the country, the mission in evangelical work, and the companies in expanding their enterprises.

The Belgian colonial system was a specific variant of the colonial model of accumulation, a model which introduced a systematic political bias in the distribution of the economic surplus in favor of the Belgian colonizers. Management of the economy was directed to providing raw materials for industry in Belgium and to support financially the Belgian cities, infrastructure and economy, which were affected and damaged by the World Wars, as well as to support Belgian settlers in the Congo who came to work for their own profits.

The colonial agricultural policy was highly authoritarian in its methods, directing farmers when and how to cultivate; it also means that farmers had few skills to draw on after the abrupt departure of the Belgian administration ${ }^{31}$. The Belgian colonial system did not have much room for the welfare of the Congolese people.

The colonial period achieved significant growth, however. This "economically efficient" outcome may be interpreted as resulting from a bargaining equilibrium among the members of the trinity, which was able to consistently produce decisions which furthered growth. The brunt of the taxation in kind, in cash, and in the form or labor was borne by the Congolese people in general, and the peasant populations in particular.

${ }^{31}$ Country Profile: Zaïre, (London: The Economist Intelligence Unit, 1996-1997), 18.

${ }^{31}$ Crawford Young, Politics in the Congo. Decolonization and Independence, 64-66. 
Low population density and the imperative of controlling access to mineral rights led to a highly centralized and coercive colonial state, unusually centralized and coercive compared to other colonial regimes. Unlike in other colonial regimes, local elites were largely bypassed and given little stake in the economy or administration. They were therefore unable to challenge the colonial state, or bargain for their own gain or the gain of their local populations.

The Belgians never really anticipated the end of their colonial rule and their centralized and coercive apparatus had prevented them from preparing the country for selfrule and a successful transition. In early 1960, there were only sixteen Congolese college graduates. Belgian leaders and other Europeans who lived in the Congo at that time encouraged tribal rivalries and hostilities among Congolese as strategy of divide and rule.

In the mid-1950s the Belgian authorities released a plan for the enfranchisement of the colony over a 30-year period. Though broadly well-accepted, the plan was rejected by Joseph Kasavubu's Alliance de Ba-Kongo (ABAKO). The fact that most French and British colonies were about to be granted sovereignty, together with the panic that followed the killing of some 50 protesters during an illegal ABAKO demonstration in January 1959, forced the Belgian government to reconsider its timetable for independence.

A conference held in Brussels in 1959 with African representatives decided to grant the Congo its independence on June $30,1960^{32}$. It has been assumed, however, that Belgian colonial rule would have lived longer than it did if it had created conditions for a sustainable capitalistic development within and outside the modern sector as well as associate Congolese in the administration and the management of the colony at the grass roots level.

Since its independence, Congo has undergone the following regimes: the First Republic (1960-1965), the Second Republic, including the Transition Period (November 24, 1965-May 17, 1997), and the Kabila Regime (May 17, 1997 to the present).

The First Republic was led by President Joseph Kasavubu and Prime Minister Patrice Emery Lumumba. The new regime could not rely on coercive compliance and the high degree of centralization was immediately challenged. Thus the transfer of formal political power from the Belgian colonizers to the newly independent republic induced a general and thorough weakening in the state.

The weakened state was equally incapable of collecting tax revenues, which decreased by 10 percent in two years. The low tax base was accompanied by increased state expenditure, and state coffers were the sole financial sources for the newly ruling elites, who attempted to build themselves an economic base and to transform themselves into an economic bourgeoisie. Under those circumstances, economic production suffered

\footnotetext{
${ }^{32}$ Mondonga M. Mokoli, State Against Development: The Experience of Post-19965 Zaïre, 3-6.
} 
and productivity decreased. This overall situation led to political instability, civil war and military coup d'état.

The Second Republic, including the Transition Period was led by Mobutu Sese Seko who took office after a military coup. In order to rule Zaïre, Mobutu created a highly centralized and coercive state, thus reproducing two of the key features of the colonial state. He undermined or co-opted competitors. The absence of equally powerful groups prevented the emergence of self-sustaining representative institutions. The lack of accountability led to the dissipation of potential revenues into bureaucratic fiefdoms, economic privilege, and corruption.

The Mobutu regime has been characterized as a patrimonial state with many feudal characteristics in the sense that the regime functioned as the extension of Mobutu's traditional household or as his private domain. The political administration of that regime was treated as a purely personal affair of Mobutu and political power was considered part of his personal property. The officials acted as personal representatives of Mobutu and they were chosen more for their loyalty and dependence than for their training, expertise, or competence. The military force was only semiprofessional in character and often included a mixture of mercenaries, aliens, societal marginals, and rural poor.

Thus, the Mobutu regime was a mixture of traditionalism and arbitrariness. It floundered due to the lack of an adequate revenue to finance essential state functions, lack of maintenance of means of coercion, inefficient administration and a corrupt bureaucracy, lack of representative institutions, and lack of a bargaining equilibrium with independent and sufficiently powerful competing forces. The state lacked the ability to design and implement a coherent development policy that could generate growth and alleviate hunger and abject poverty ${ }^{33}$.

The current regime is under Kabila, who took office in May 1997 after overthrowing Mobutu by a rebellion that was initially welcomed by the people of the Congo. That rebellion was supported and sponsored by the Vice President of Rwanda, the Presidents of Uganda, Burundi, and Angola, and facilitated by the mediation led by South Africa and mainly the United States. So far, Kabila has been using the same approach and strategy as Mobutu, but with different tactics, and so is missing the opportunity to create the prerequisites for a stable and development-oriented state in the Congo.

In summation, the pathology of state formation in the Democratic Republic of the Congo is rooted in the internal factors, as well as in the external ones, including the historical and material legacy of the Belgian colonialism and of the Cold War. Both internal and external factors have been responsible for the lack of the creation of the prerequisites for a stable and development-oriented state in the Congo.

\footnotetext{
${ }^{33}$ Mondonga M. Mokoli, The Transition Towards Democracy in Post-1990 Zaïre: Contradictions and Dilemma, 1-170.
} 


\section{SELECTED BIBLIOGRAPHY}

"Adjustment and the State: The Problem of Administrative Reform." in Institute of Development Studies Bulletin. Vol. 19, no 4, (October 1988), 1-63.

Alapuro, Risto. "Peasants, States, and the Capitalist World System," in Acta-Sociologica. Marankatu, Finland: Research Group on Comparative Sociology, 1997.

Alavi, Hamza. "The State in Postcolonial Societies: Pakistan and Bangladesh." in New Left Review. no. 74, (July-August, 1972), 59-82.

Anderson, Perry. Leneages of the Absolutist State. London: New Left Books, 1974.

Anderson, Perry. Passages from Antiquity to Feudalism. London: New Left Books, 1974a.

Ardant, Gabriel. "Financial Policy and Economic Infrastructure of Modern States and Nations," in Charles Tilly (ed.). The Formation of National States in Western Europe. Princeton, New Jersey: Princeton University Press, 1975.

Badie, Bertrant. Le Développement Politique. 2 ed., Paris: Economica, 1980.

Bates, Robert H. Markets and States in Tropical Africa. Political Economy. Basis of Agricultural Policies. Los Angeles: University of California Press, 1981.

Berger, Peter and Neuhaus, Richard. To Empower People. The Role of Mediating Structures in Public Policy, Political and Social Processes. Washington, D.C.: American Enterprises Institute, 1997.

Bertrand, Hugues. Le Congo: Formation Sociale et Mode de Développement Economique. Paris: François Maspero, 1975.

Birnbaum, Pierre. States and Collective Action: The European Experience. Cambridge: Cambridge University Press, 1988.

Bloch, Marc. La Société Féodale. 2 volumes. Translated by L.A. Manyon, Chicago: University of Chicago Press, 1961.

Bloch, Marc. La Sociéte Féodale. La Formation des Liens de Dépendance. Les Classes et le Gouvernement des Hommes. Paris: Editions Albins Michels, 1968.

Bottomore, Tom. Theories of Modern Capitalism. Massachusetts: Allen \& Unwin, Winchester, 1985a.

Bottomore, Tom et al. (eds). A Dictionary of Marxist Thought. United States of America: Harvard, 1983. 
Bournazel, E. and Poly, J.P. La Mutation Féodale. X-XII Siècle. Paris: Presses Universitaires de France, 1980.

Brenner, Robert. "Agrarian Class Structure and Economic Development in Pre-Industrial Europe Past and Present." 70 (1976), 30-75.

Burton, Michael G. and Higgley, John. "Elite Settlements," pp.295-307, American Sociological Review. Volume 52, 1987.

Carnoy, Martin. The State and Political Theory. New Jersey: Princeton University Press, 1984.

Clark, Gordon L. and Dear, Michael. State Apparatus. Structures and Language of Legitimacy. Boston, MA: Allen \& Unwin, 1984.

Clive, Thomas Y. The Rise of the Authoritarian State in Peripheral Societies. New York: Monthly Review, 1984.

Cohen, Y. et al. "The Paradoxical Nature of State -Making: The Violent Creation of Order," in American Political Science Review. 75 (1981), 901-910.

Corrigan, Phil. Capitalism, State Formation and Marxist Theory. Historical Investigations. London: Quartet Books, 1980.

Coulborn, Rushton (ed). Feudalism in History. Princeton: Princeton University Press, 1956.

Crosier, Michell, et al. The Crisis of Democracy. New York: New York University Press, 1975.

Delort, Robert. La Vie au Moyen Age. Paris: Edition du Seuil, 1982.

Dobb, Maurice et al. The Transition From Feudalism to Capitalism. Great Britain: The Thetford Press, 1984.

Dobb, Maurice. Studies in Development of Capitalism. London: Routledge \& Kegan Paul, 1963.

Dommen , Edward and Philippe, Hein. States, Microstates, and Islands. London, Dover, N.H.: Croom Helm, 1973.

Duby, Georges. La Vie Au Moyen-Age. Paris: Flammarion, 1988.

Duby, Georges. L'Europe Au Moyen-Age. Paris: Flammarion, 1984.

Duby, Georges. Premier Essor de l'Economie Européenne. Paris: Gualimard, 1973.

Dumont, René et Mottin, M.F. L'Afrique Etranglée. Paris: Editions du Seuil, 1980. 
Earle, Timothy K. "Chiefdoms in Archeological and Ethnohistorical Perspective," Annual Review of Anthropology. 16: 279-308.

Eisenstadt, S.N. The Political States of Empires. New York: Free Press, 1963.

Ekeh, Peter. "Reform Africa Estrangled States." in Journal of Economic Literature. vol.31. no.4, (December 1993), 117-119.

Forbes, Dean K. The Geography of Underdevelopment: A Critical Survey. London: Croom Helm, c1984.

Gilpin, Robert. "The Theory of Hegemonic War," in Journal of Interdisciplinary History. 18 (2988), 591-614.

Halmiton, Nora. The Limits of State Autonomy: Post-Revolutionary Mexico. Princeton, New Jersey: Princeton University Press, 1982.

Hankins, Frank H. An Introduction to the Study of Society. An Outline of Primary Factors and Fundamental Institutions. New York: The MacMillan Company, 1928.

Heer, Friedrich. The Medieval World. Canada: Mentor, 1962.

Higley, John and Burton, Michael G. "The Elite Variable in Democratic Transitions and Breakthrough." 21. American Sociological Review. Vol 54, 1989.

Hilton, Rodney et al. The Decline of Serfdom in Medieval England. London: Macmillan, 1992.

Hilton, Rodney et al. The Transition from Feudalism to Capitalism. London: Thetford Press, 1984.

Hood, Michael. The Economies of Africa. Boston: MA: G.K. Hall \& Co., 1991.

Huntington, Samuel. Political Order in Changing Societies. New Haven, Conn.: Yale University Press, 1968.

Ingrao, Pietro. Theories of States. New York: New York University Press, 1983.

Jones, Grant D. and Kautz, Robert R. (eds). The Transition to Statehood in the New World. New York: Cambridge University Press, 1981.

Kennedy, Paul. The Rise and Fall of the Great Powers. Economic Change and Military Conflict from 1500 to 2000. New York: Random House, 1987.

Kriedte, Peter. Peasants, Landlords and Merchant Capitalists: Europe and World Economy, 1500-1800. Cambridge: Cambridge University Press, 1983 
Kubota, Isao. "Roles that Governments Play in Developing, Developed States." Japan Times, (June 17, 1996), p.15.

Linz, Juan J., Seymour Martin Lipset, and Bunger Pool. "Social Conditions for Democracy in Latin America." Latin American Barometer Survey Analysis. New Haven, Conn.: Yale University.

Magdoff, Harris. Imperialism: From the Colonial Age to the Present. New York: Monthly Review Press, 1983.

Marx, Karl. Capital. A Critique of Political Economy. vol. 1., New York: International Publishers, 1966/1967.

Mazumdar, Krishma. "An Analysis of Causal Flow Between Social Development and Economic Growth: The Social Development Index," in The American Journal of Economics and Sociology, vol 5, no 3, (July, 1996), 361-381.

Milliband, R. State in Capitalist Society. New York: Basic Books, 1969.

Mokoli, Mondonga M. "La Démocratie dans le Féodalisme: Tout le Noeud du Blocage de la Transition Vers la Troisième République au Zaïre." in Bulletin de la Faculté de Droit, no 3, (septembre 1994), 83-104.

Mokoli, Mondonga M. State Against Development: The Experience of Post-1965 Zaïre. Westport, Conn.: Greenwood Press, 1992.

Mokoli, Mondonga M. The Transition Towards Democracy in Post-1990: Contradictions and Dilemma. San Francisco, London, and Bethesda: International Scholars Publications, 1997.

Moore, Barrington Jr. Social Origins of Dictatorship and Democracy: Lord and Peasant in the Making of the Modern World. Boston: Beacon Press, 1967.

Mueller, Dennis C. The Political Economy of Growth. New Haven: Yale University Press, 1983.

Nelson, Daniel N. (ed). After Authoritarianism: Democracy or Disorder. Westport, Conn.: Greenwood Press, 1995.

Nelson, Joan M., Tilly, Charles, and Walker, Lee (eds). Transforming Post-Communist Political Economies. Washington, D.C.: National Academy Press, 1997.

Ottaway, Marina. Democratization and Ethnic Nationalism: African and Eastern European Experiences. Policy Essay No. 14. Washington, D.C.: Overseas Development Council, 1994.

Parain, Charles. Les Caractères Généraux du Féodalisme. Paris: Editions Sociales, 1971. 
Petit-Dutaillis, Charles. La Monarchie Féodale en France et en Angleterre. Paris: Croom Helm, 1983.

Rokkan, Stein. "Dimensions of State Formation and Nation-Building: A Possible Paradigm for Research on Variations Within Europe." in Charles Tilly (ed.). The Formation of National States in Western Europe. Princeton, New Jersey: Princeton University Press, 1975.

Rosenau, James N. The Adaptation of National Societies: A Theory of Political System Behavior and Transformation. New York: McCaleb-Seiler, 1970.

Rueschemeyer, D. and Evans, Peter. "The State and Economic Transformation," in Peter Evans et al. (ed.). Bringing the State Back In. New York: Cambridge University Press, 1985.

Sanderson, Stephen K. Social Transformations: A General Theory of Historical Development. Cambridge, MA: Blackwell, 1995.

Sanderson, Stephen K. Macrosociology. An Introduction to Human Societies. New York: Harper \& Row Publishers, 1988.

Tainter, Joseph A. The Collapse of Complex Societies. New York: Cambridge Press, 1988.

Taylor, John. From Modernization to Mode of Production. New Jersey: Humanities Press, 1979.

Taylor, Lance. Macro Models for Developing Countries. New York: McGraw-Hill, c1979.

Tilly, Charles. Coercion, Capital, and European States, AD 990-1990. Cambridge, Mass.: Basil Blackwell, 1990.

Tilly, Charles (ed.). The Formation of National States in Western Europe. Princeton: Princeton University Press, 1975.

Ungar, Sanford J. Africa: The People and Politics of an Emerging Continent. New York: Free Press, 1972.

Urry, J. The Anatomy of Capitalist Societies: The Economy, Civil Society, and the State. Atlantic Highlands: Humanities, 1981.

United Nations Development Programme. Reconceptualizing Governance. Discussion Paper 2. New York, NY: Management Development and Governance Division, Bureau for Policy and Programme Support, United Nations Development Programme, 1997. 
Wallerstein, Emmanuel. The Modern World System. 3 vols. New York, and Orlando, Florida: Academic Press, 1974-1988.

Wendt, Alexander and Barnett, Michael. "Dependent State Formation and Third World Militarization." in International Studies, Vol 19, no 2, (April 1933), 322.

World Bank. World Development Report 1997. The State In A Changing World. Washington, D.C.: Oxford University Press, 1997.

Willame, Claude J. Patrimonialism and Political Change in the Congo. Stanford, California: Stanford University Press, 1972.

Yoffee, Norman and CowGill, George (eds). The Collapse of Ancient States and Civilizations. Tucson: University of Arizona Press, 1988.

Zartman, William I., (ed). Collapsed States: The Disintegration and Restoration of Legitimate Authority. Boulder, Colo., and London: Lynne Rienner, 1995. 